\title{
Puerarin reduces increased c-fos, c-jun, and type IV collagen expres- sion caused by high glucose in glomerular mesangial cells
}

\author{
Cai-ping MAO, Zhen-lun GU ${ }^{1}$ \\ Department of Pharmacology, Suzhou Institute of Chinese Materia Medica,Medical College of Soochow University, Suzhou 215007, China
}

\section{Key words}

puerarin; glomerular mesangial cells; extracellular matrix; diabetic nephropathy

${ }^{1}$ Correspondence to Prof Zhen-lun GU

$\mathrm{Phn} / \mathrm{Fax}$ 86-512-519-0599.

E-mail zhenlungu.2003@163.com

Received 2004-12-07

Accepted 2005-04-04

doi: $10.1111 / \mathrm{j} .1745-7254.2005 .00133 . x$

\begin{abstract}
Aim: Increased expression of c-fos, c-jun and type IV collagen (CoIV) in glomerular mesangial cells (GMC) are important characteristics of diabetic nephropathy. Both c-fos and c-jun regulate the gene expression of extracellular matrix components, and CoIV is the main component of the extracellular matrix. It has been reported that puerarin inhibits aggregation of the extracellular matrix in diabetic rats by an as yet unknown mechanism. The aim of this study is to investigate the effect of puerarin on c-fos, c-jun and CoIV expression in GMC cultured in medium containing 5.6 or $27.8 \mathrm{mmol} / \mathrm{L}$ glucose. Methods: The expressions of c-fos and c-jun were measured at the protein level using flow cytometry. CoIV content was detected using radioimmunoassay. Protein kinase $\mathrm{C}$ (PKC) activity was measured using liquid scintillation counting. Results: Puerarin $\left(10^{-5} \mathrm{mmol} / \mathrm{L}\right)$ significantly ameliorated the high-glucose effect on c-fos, c-jun and CoIV expression. This effect is accompanied by a reduced PKC activity in these cells. Conclusion: Our results suggest that reduced PKC activity and expression of c-fos and c-jun in GMC might participate in the mechanisms underlying the therapeutic effect of puerarin on diabetic nephropathy.
\end{abstract}

\section{Introduction}

Glomerular mesangial cells (GMC), the major cell type synthesizing and excreting extracellular matrix (ECM) components and various cellular factors, are one of the major indispensable glomerular cells. GMC proliferation can lead to the excess production and accumulation of ECM, whose progressive accumulation is an important character of diabetic nephropathy in its early stages, which can lead to glomerulosclerosis ${ }^{[1]}$. Recent data suggest that progressive ECM accumulation can be detected by increasing levels of $c$-fos and $c$-jun oncogene mRNA in the early stages of diabetic rats. The expression products of $c$-fos and $c-j u n$ form a steady dimer (activated protein-1, AP-1), which translocates from the cytosol to the cell membrane and binds to specific sequences of certain ECM gene promoters, regulating the transcription and expression of ECM components ${ }^{[2]}$. AP-1 activity can be regulated by various protein kinases as well as protein modulation after its synthesis and translocation. Protein kinase $\mathrm{C}(\mathrm{PKC})$ is an important molecule in cellular signaling transcription pathways, where it is located upstream of c-fos and c-jun. Diabetes-induced PKC activation can induce diabetic nephropathy, for example, by modifying cytoskeleton proteins, regulating ECM gene expression and promoting growth factor transcription ${ }^{[3,4]}$.

Puerarin is one of the major effective extract from the radix of Puerarin Lobata (wild) ohwi and P thomsonii Benth. Modern pharmacology has demonstrated that puerarin can activate blood and eliminate stasis, improve micro-circulation, inhibit aldose reductase activity and decrease blood glucose. Furthermore, it has been shown to have clinical applications in the treatment of coronary heart disease, angina, myocardial infarction and diabetic nephropathy ${ }^{[5]}$. In the diabetic nephropathy rat model where the kidney is unilaterally removed, hypertrophy of the glomerular basement membrane and increased PKC activity of the glomerular membrane have been reported ${ }^{[3]}$. Puerarin can inhibit aggregation of the ECM and improve translocation of PKC to the cell membrane. However, it is not known whether high glucose regulates protein expressions of c-fos and c-jun by activating PKC, 
nor has the underlying mechanism by which puerarin preventing against diabetic nephropathy been fully demonstrated. In the present study, we investigate changes in protein expressions of c-fos and c-jun, CoIV synthesis and PKC activity of GMC cultured under high glucose conditions. We also investigated puerarin's effect on these changes in order to explain the underlying mechanism by which diabetic nephropathy occurs and develops.

\section{Materials and methods}

Chemicals and reagents Puerarin was purchased from Guangdong Yantang Biochemistry (2 mL/100 mg, № 040310; Guangdong, China). Cell culture medium RPMI-1640 (containing $5.6 \mathrm{mmol} / \mathrm{L}$ or $27.8 \mathrm{mmol} / \mathrm{L}$ glucose) was purchased from Gibco (USA). Ethidium bromide and bromophenol blue were the products of Sigma (USA). CoIV radioimmunoassay analysis kit was the product of Shanghai Haiyan Medical Bio-tech Institute (№ 20040328; Shanghai, China). Breaking membrane reagent, and c-fos and c-jun rabbit anti-rat monoclonal antibodies and goat anti-rabbit IgG-fluorescein-isothiocyanate (FITC) were purchased from Santa Cruz Inc (USA). PKC protein kinase assay kit was purchased from Gibco (№ 20040220; USA).

Cell culture The rat GMC cell line ${ }^{[6]}$ purchased from the Nephropathy Laboratory of the Second Military Medical University Changzheng Hospital (Shanghai, China) was plated in 10\% RPMI-1640 containing $10 \%$ fetal bovine serum (FBS, Gibco), averaged into 2 culture containers $(5 \mathrm{~mL}$ in each container), and cultured in a humidified atmosphere of $95 \%$ air and $5 \% \mathrm{CO}_{2}$ at $37{ }^{\circ} \mathrm{C}$. Before the experiment, cells were pre-incubated with RPMI-1640 culture medium without FBS. After $48 \mathrm{~h}, \mathrm{GMC}$ were cultured and divided into five groups: (i) RPMI-1640 containing $5.6 \mathrm{mmol} / \mathrm{L}$ glucose; (ii) RPMI-1640 containing $27.8 \mathrm{mmol} / \mathrm{L}$ glucose; (iii) RPMI-1640 containing $27.8 \mathrm{mmol} / \mathrm{L}$ glucose + puerarin $\left(10^{-5} \mathrm{~mol} / \mathrm{L}\right)$; (iv) RPMI-1640 containing $27.8 \mathrm{mmol} / \mathrm{L}$ glucose + puerarin $\left(1 \times 10^{-6}\right.$ $\mathrm{mol} / \mathrm{L}$ ); (v) RPMI-1640 containing $27.8 \mathrm{mmol} / \mathrm{L}$ glucose + puerarin $\left(1 \times 10^{-7} \mathrm{~mol} / \mathrm{L}\right)$. Each group was incubated in $5 \%$ $\mathrm{CO}_{2}$ at $37^{\circ} \mathrm{C}$.

Detection of c-fos and c-jun protein expression in GMC using flow cytometry Glomerular mesangial cells $\left(2 \times 10^{6}\right)$ were collected after they were cultured for $24 \mathrm{~h}, 48 \mathrm{~h}$, or $96 \mathrm{~h}$. Breaking membrane reagent 1 (Santa Cruz Inc, USA) was added to cell pellets, which were homogenized, fixed at $25^{\circ} \mathrm{C}$ for $15 \mathrm{~min}$, washed with phosphate-buffered saline (PBS) and centrifuged at $300 \times \mathrm{g}$ for $5 \mathrm{~min}$, and the supernatant was removed. Breaking membrane reagent 2 was then added to the remaining pellet, which was homogenized, dissolved at $25^{\circ} \mathrm{C}$ for $5 \mathrm{~min}$ and incubated with rabbit anti-rat c-fos or c- jun protein polyclonal antibodies for $30 \mathrm{~min}$ at $25{ }^{\circ} \mathrm{C}$. The first antibody was then washed out using PBS, and cells were incubated at $25^{\circ} \mathrm{C}$ for $20 \mathrm{~min}$ with goat anti-rabbit IgGFITC. After the second PBS washes, cells were suspended in $0.5 \%$ formaldehyde and detected using a flow cytometer (Becton Dickinson Co, USA). The Cell Quest ${ }^{\mathrm{TM}}$ analysis system was used to detect c-fos and c-jun positive cells

Type IV collagen content in the supernatant of GMC After GMC $\left(1 \times 10^{6}\right)$ were cultured for $24 \mathrm{~h}, 48 \mathrm{~h}$ or $96 \mathrm{~h}$, the supernatants from the cell cultures were collected to measure CoIV content using a competitive radioimmunoassay. Samples were homogenized with type-IV-collagen labeled by ${ }^{125} \mathrm{I}$, incubated at $4{ }^{\circ} \mathrm{C}$ overnight. The secondary antibody was then added to the assay system and incubated at $4{ }^{\circ} \mathrm{C}$ for $60 \mathrm{~min}$. The supernatant was removed by centrifugation at $10000 \times \mathrm{g}$ for $10 \mathrm{~min}$ and the radioactivity in the pellet was counted.

Protein kinase C activity After GMC $\left(2 \times 10^{6}\right)$ had been treated for $24 \mathrm{~h}$, the homogenate was prepared with $2 \mathrm{~mL}$ PBS, and centrifuged at $100000 \times g\left(4^{\circ} \mathrm{C}\right)$ for $1 \mathrm{~h}$. The supernatant containing PKC from the cytosol, was collected and stored separately. PBS containing $0.1 \%$ Triton X-100 was added to the pellet. The mixture was bathed in ice, extracted for $30 \mathrm{~min}$, centrifugated at $100000 \times g\left(4{ }^{\circ} \mathrm{C}\right)$ for $30 \mathrm{~min}$, and the remaining particles are PKC. The protein content was measured using a coomassie brilliant blue assay (to quantify PKC activity), and PKC activity was measured using a liquid scintillation counter (LS2000; Beckman Coulter, USA). The units are presented as $\mathrm{pmol} \cdot \mathrm{min}^{-1} \cdot \mathrm{mg}^{-1}$ protein.

Statistical methods Differences between groups were analyed by one-way ANOVA with SPSS 10.0 software, and the results were expressed as mean \pm SD. $P<0.05$ was considered to be statistically significant.

\section{Results}

Protein expressions of c-fos and c-jun in different GMC groups Of the GMC cultured in RPMI-1640 for $24 \mathrm{~h}, 48 \mathrm{~h}$ and $96 \mathrm{~h}$, protein expression of c-fos and c-jun was higher in the $27.8 \mathrm{mmol} / \mathrm{L}$ glucose group than in the $5.6 \mathrm{mmol} / \mathrm{L}$ glucose group $(P<0.01)$. At $24 \mathrm{~h}$ and $48 \mathrm{~h}$, protein expression of c-fos and c-jun in cells cultured in RPMI-1640 containing 27.8 $\mathrm{mmol} / \mathrm{L}$ glucose + puerarin $\left(1 \times 10^{-5} \mathrm{~mol} / \mathrm{L}\right)$ decreased significantly compared with those cultured in $27.8 \mathrm{mmol} / \mathrm{L}$ glucose alone $(P<0.05)$. At $96 \mathrm{~h}$, protein expression of $\mathrm{c}$-jun was still increased, but protein expression of c-fos decreased. At $48 \mathrm{~h}$, protein expression of c-fos and c-jun in the $27.8 \mathrm{mmol} / \mathrm{L}$ glucose+puerarin $\left(10^{-6} \mathrm{~mol} / \mathrm{L}\right)$ group decreased markedly compared with cells cultured in RPMI-1640 containing 27.8 $\mathrm{mmol} / \mathrm{L}$ glucose alone $(P<0.05)$. These results suggest that 
protein expression of c-fos and c-jun in GMC may be increased at an early stage after treatment with high concentrations of glucose $(27.8 \mathrm{mmol} / \mathrm{L})$, but the increase in c-jun expression was sustained for longer than that of c-fos, Puerarin can inhibit GMC protein expression of c-fos and cjun under high concentrations of glucose $(27.8 \mathrm{mmol} / \mathrm{L})$ (Tables 1, 2)

Type IV collagen synthesis in different GMC groups At $24 \mathrm{~h}, 48 \mathrm{~h}$ and $96 \mathrm{~h}$ of the investigation, CoIV synthesis in the $27.8 \mathrm{mmol} / \mathrm{L}$ glucose group was higher than in the $5.6 \mathrm{mmol} / \mathrm{L}$ glucose group $(P<0.05)$. CoIV synthesis in the $27.8 \mathrm{mmol} / \mathrm{L}$ group was also higher than in the $27.8 \mathrm{mmol} / \mathrm{L}$ glucose+ puerarin $\left(10^{-5}\right.$ and $\left.10^{-6} \mathrm{~mol} / \mathrm{L}\right)$ groups $(P<0.05)$. These results indicate that high glucose concentrations $(27.8 \mathrm{mmol} / \mathrm{L}) \mathrm{can}$ increase CoIV synthesis in GMC, which can be partly inhibited by puerarin (Table 3 ).

Protein kinase activity in different GMC groups At $24 \mathrm{~h}$ and $48 \mathrm{~h}$ of the investigation, the PKC activity in the cytosol decreased. However, in the granule (which included membrane and nucleolus) of the high glucose concentration
Table 3. Effect of puerarin on type IV collagen in glomerular mesangial cells. $n=6$. Mean \pm SD. ${ }^{\mathrm{b}} P<0.05,{ }^{\mathrm{c}} P<0.01$ vs $5.6 \mathrm{mmol} / \mathrm{L}$ glucose. ${ }^{\mathrm{e}} P<0.05,{ }^{\mathrm{f}} P<0.01$ vs $27.8 \mathrm{mmol} / \mathrm{L}$ glucose.

\begin{tabular}{|c|c|c|c|}
\hline \multirow{2}{*}{ Group } & \multicolumn{3}{|c|}{ Type IV collagen $/ \mu \mathrm{g} \cdot \mathrm{L}^{-1}$} \\
\hline & $24 \mathrm{~h}$ & $48 \mathrm{~h}$ & $96 \mathrm{~h}$ \\
\hline Glucose $(5.6 \mathrm{mmol} / \mathrm{L})$ & $38.26 \pm 5.13$ & $57.67 \pm 7.28$ & $68.21 \pm 9.04$ \\
\hline Glucose $(27.8 \mathrm{mmol} / \mathrm{L})$ & $45.18 \pm 6.15^{b}$ & $67.55 \pm 6.45^{b}$ & $90.45 \pm 10.32^{\mathrm{c}}$ \\
\hline $\begin{array}{l}\text { Glucose }(27.8 \mathrm{mmol} / \mathrm{L}) \\
+ \text { puerarin }\left(10^{-5} \mathrm{~mol} / \mathrm{L}\right)\end{array}$ & $39.03 \pm 5.24^{\mathrm{e}}$ & $58.02 \pm 6.33^{\mathrm{e}}$ & $70.33 \pm 8.29^{\mathrm{e}}$ \\
\hline $\begin{array}{l}\text { Glucose }(27.8 \mathrm{mmol} / \mathrm{L}) \\
+ \text { puerarin }\left(10^{-6} \mathrm{~mol} / \mathrm{L}\right)\end{array}$ & $40.12 \pm 5.46$ & $59.39 \pm 7.51^{\mathrm{f}}$ & $77.96 \pm 9.21^{\mathrm{f}}$ \\
\hline $\begin{array}{l}\text { Glucose }(27.8 \mathrm{mmol} / \mathrm{L}) \\
+ \text { puerarin }\left(10^{-7} \mathrm{~mol} / \mathrm{L}\right)\end{array}$ & $43.76 \pm 6.19$ & $65.17 \pm 7.38$ & $85.68 \pm 8.63$ \\
\hline
\end{tabular}

group (containing $27.8 \mathrm{mmol} / \mathrm{L}$ glucose), PKC activity was increased significantly compared with the low glucose concentration group (containing $5.6 \mathrm{~mol} / \mathrm{L}$ glucose) $(P<0.01)$. $\mathrm{PKC}$ activity in the membrane fraction from the high glucose

Table 1. Effect of puerarin on protein expression of c-fos in glomerular mesangial cells. $n=5$. Mean \pm SD. ${ }^{b} P<0.05$, ${ }^{\mathrm{c}} P<0.01$ v Glucose $(5.6$ mmol/L). ${ }^{\mathrm{e}} P<0.05,{ }^{\mathrm{f}} P<0.01$ vs Glucose $(27.8 \mathrm{mmol} / \mathrm{L})$. FI, fluorecence intensity; PPC, percentage of positive cells.

\begin{tabular}{|c|c|c|c|c|c|c|}
\hline \multirow{2}{*}{ Group } & \multicolumn{2}{|c|}{$24 \mathrm{~h}$} & \multicolumn{2}{|c|}{$48 \mathrm{~h}$} & \multicolumn{2}{|c|}{$96 \mathrm{~h}$} \\
\hline & FI & $\mathrm{PPC}$ & FI & $\mathrm{PPC}$ & FI & PPC \\
\hline Glucose $(5.6 \mathrm{mmol} / \mathrm{L})$ & $10.54 \pm 0.87$ & $9.06 \pm 0.84$ & $12.62 \pm 1.56$ & $10.41 \pm 0.81$ & $10.86 \pm 1.33$ & $8.96 \pm 1.25$ \\
\hline Glucose $(27.8 \mathrm{mmol} / \mathrm{L})$ & $13.16 \pm 1.29^{c}$ & $10.97 \pm 1.04^{\mathrm{c}}$ & $14.96 \pm 1.44^{\mathrm{b}}$ & $11.53 \pm 0.96^{\mathrm{b}}$ & $12.18 \pm 1.07$ & $10.11 \pm 1.63$ \\
\hline $\begin{array}{l}\text { Glucose }(27.8 \mathrm{mmol} / \mathrm{L}) \\
+ \text { puerarin }\left(10^{-5} \mathrm{~mol} / \mathrm{L}\right)\end{array}$ & $10.62 \pm 0.91^{\mathrm{f}}$ & $9.51 \pm 0.87^{\mathrm{f}}$ & $13.12 \pm 0.95^{\mathrm{e}}$ & $10.28 \pm 0.71^{\mathrm{e}}$ & $11.38 \pm 1.43$ & $9.56 \pm 1.39$ \\
\hline $\begin{array}{l}\text { Glucose }(27.8 \mathrm{mmol} / \mathrm{L}) \\
+ \text { puerarin }\left(10^{-6} \mathrm{~mol} / \mathrm{L}\right)\end{array}$ & $11.84 \pm 1.21$ & $9.94 \pm 0.65$ & $13.31 \pm 1.29^{\mathrm{e}}$ & $10.39 \pm 1.02^{\mathrm{e}}$ & $11.90 \pm 1.02$ & $9.77 \pm 1.26$ \\
\hline $\begin{array}{l}\text { Glucose }(27.8 \mathrm{mmol} / \mathrm{L}) \\
+ \text { puerarin }\left(10^{-7} \mathrm{~mol} / \mathrm{L}\right)\end{array}$ & $12.81 \pm 1.35$ & $10.42 \pm 0.92$ & $14.51 \pm 0.82$ & $10.81 \pm 0.82$ & $11.88 \pm 0.95$ & $10.03 \pm 1.04$ \\
\hline
\end{tabular}

Table 2. Effect of puerarin on protein expression of c-jun in glomerular mesangial cells. $n=5$. Mean \pm SD. ${ }^{b} P<0.05,{ }^{\mathrm{c}} P<0.01 \quad v s$ Glucose $(5.6$ $\mathrm{mmol} / \mathrm{L})$. ${ }^{\mathrm{e}} P<0.05,{ }^{\mathrm{f}} P<0.01$ vs Glucose $(27.8 \mathrm{mmol} / \mathrm{L})$. FI, fluorescence intensity; PPC, percentage of positive cells.

\begin{tabular}{|c|c|c|c|c|c|c|}
\hline \multirow{2}{*}{ Group } & \multicolumn{2}{|c|}{$24 \mathrm{~h}$} & \multicolumn{2}{|c|}{$48 \mathrm{~h}$} & \multicolumn{2}{|c|}{$96 \mathrm{~h}$} \\
\hline & FI & PPC & FI & PPC & FI & PPC \\
\hline Glucose $(5.6 \mathrm{mmol} / \mathrm{L})$ & $14.98 \pm 0.72$ & $10.65 \pm 0.92$ & $15.04 \pm 0.76$ & $10.40 \pm 0.68$ & $15.82 \pm 0.67$ & $10.91 \pm 1.37$ \\
\hline Glucose $(27.8 \mathrm{mmol} / \mathrm{L})$ & $19.06 \pm 0.88^{c}$ & $10.97 \pm 1.18^{c}$ & $19.13 \pm 1.02^{\mathrm{c}}$ & $14.32 \pm 0.94^{\mathrm{c}}$ & $17.36 \pm 1.42^{\mathrm{b}}$ & $12.73 \pm 0.89^{\mathrm{b}}$ \\
\hline $\begin{array}{l}\text { Glucose }(27.8 \mathrm{mmol} / \mathrm{L}) \\
+ \text { puerarin }\left(10^{-5} \mathrm{~mol} / \mathrm{L}\right)\end{array}$ & $16.23 \pm 0.75^{\mathrm{f}}$ & $12.61 \pm 1.34^{\mathrm{f}}$ & $16.09 \pm 1.23^{\mathrm{e}}$ & $11.96 \pm 0.72^{\mathrm{e}}$ & $15.51 \pm 0.88^{\mathrm{f}}$ & $11.64 \pm 0.73^{\mathrm{f}}$ \\
\hline $\begin{array}{l}\text { Glucose }(27.8 \mathrm{mmol} / \mathrm{L}) \\
+ \text { puerarin }\left(10^{-6} \mathrm{~mol} / \mathrm{L}\right)\end{array}$ & $17.79 \pm 0.91$ & $13.67 \pm 0.85^{\mathrm{e}}$ & $17.43 \pm 0.81^{\mathrm{f}}$ & $12.99 \pm 0.82^{\mathrm{f}}$ & $15.96 \pm 1.21$ & $11.76 \pm 0.81$ \\
\hline $\begin{array}{l}\text { Glucose }(27.8 \mathrm{mmol} / \mathrm{L}) \\
+ \text { puerarin }\left(10^{-7} \mathrm{~mol} / \mathrm{L}\right)\end{array}$ & $18.24 \pm 0.69$ & $14.22 \pm 0.69$ & $18.75 \pm 0.94$ & $13.83 \pm 1.09$ & $16.35 \pm 1.36$ & $12.58 \pm 0.48$ \\
\hline
\end{tabular}


(containing $27.8 \mathrm{mmol} / \mathrm{L}$ glucose) + puerarin $\left(10^{-5} \mathrm{~mol} / \mathrm{L}\right)$ group decreased significantly compared with the high glucose concentration group (containing $27.8 \mathrm{mmol} / \mathrm{L}$ glucose). These results suggest that $\mathrm{PKC}$ can translocate from the cytosol of GMC to the membrane under conditions of high glucose concentrations, resulting in a sustained increase in PKC activity in the membrane. Puerarin can apparently inhibit such membrane translocation (Table 4).

Table 4. Effect of puerarin on protein kinase C (PKC) activity in glomerular mesangial cells. $n=6$. Mean \pm SD. ${ }^{\mathrm{b}} P<0.05,{ }^{\mathrm{c}} P<0.01$ vs 5.6 mmol/L glucose. ${ }^{\mathrm{e}} P<0.05,{ }^{\mathrm{f}} P<0.01$ vs $27.8 \mathrm{mmol} / \mathrm{L}$ glucose.

\begin{tabular}{lccc}
\hline & \multicolumn{2}{c}{ PKC activity $/ \mathrm{pmol} \cdot \mathrm{min}^{-1} \cdot \mathrm{mg}^{-1}$ protein } \\
Group & Cytosol & Membrane & Total \\
& & & \\
\hline & & & \\
Glucose $(5.6 \mathrm{mmol} / \mathrm{L})$ & $112.3 \pm 10.6$ & $39.7 \pm 9.6$ & $151.3 \pm 10.2$ \\
Glucose $(27.8 \mathrm{mmol} / \mathrm{L})$ & $95.6 \pm 8.2^{\mathrm{c}}$ & $198.2 \pm 17.3^{\mathrm{c}}$ & $294.7 \pm 14.9^{\mathrm{c}}$ \\
Glucose $(27.8 \mathrm{mmol} / \mathrm{L})$ & $108.2 \pm 6.3^{\mathrm{f}}$ & $59.1 \pm 8.9^{\mathrm{e}}$ & $168.5 \pm 8.1^{\mathrm{e}}$ \\
+ puerarin $\left(10^{-5} \mathrm{~mol} / \mathrm{L}\right)$ & & & \\
Glucose $(27.8 \mathrm{mmol} / \mathrm{L})$ & $105.4 \pm 7.5^{\mathrm{e}}$ & $76.5 \pm 10.3^{\mathrm{e}}$ & $174.9 \pm 8.7^{\mathrm{e}}$ \\
+ puerarin $\left(10^{-6} \mathrm{~mol} / \mathrm{L}\right)$ & & & \\
Glucose $(27.8 \mathrm{mmol} / \mathrm{L})$ & $97.2 \pm 6.4$ & $91.7 \pm 7.2^{\mathrm{e}}$ & $189.2 \pm 6.7^{\mathrm{e}}$ \\
+ puerarin $\left(10^{-7} \mathrm{~mol} / \mathrm{L}\right)$ & & & \\
\hline
\end{tabular}

\section{Discussion}

Recent studies demonstrate that abnormalities in GMC protein metabolism in various cells play a key role in the occurrence and development of diabetic nephropathy. GMC, the major cell type synthesizing and excreting ECM components and various cell factors, are a key factor in the occurrence and development of many diseases. The present study focused on GMC and discussed the excretion of CoIV, a main component of the ECM, on a cellular level when cells are exposed to high glucose concentrations. The results demonstrated that high glucose concentrations significantly increased CoIV content in GMC, which could be effectively inhibited by puerarin. These results are also supported by previous animal experiments ${ }^{[7]}$.

We investigated the effect of high glucose on the protein expressions of c-fos and c-jun in mesangial cells. The results suggest that when GMC are treated with a high concentration of glucose $(27.8 \mathrm{mmol} / \mathrm{L})$ for $24 \mathrm{~h}$ and $48 \mathrm{~h}$, nuclear protein expression levels are higher than following treatment with a low concentration of glucose $(5.6 \mathrm{mmol} / \mathrm{L})$. However, when treated with a high concentration of glucose $(27.8 \mathrm{mmol} /$ L) for $96 \mathrm{~h}$, c-fos nuclear protein level is approximately the same as that in the low glucose concentration $(5.6 \mathrm{mmol} / \mathrm{L})$ group, while c-jun nuclear protein content continues to increase, which is the same result as in other studies ${ }^{[8]}$. This suggests that high concentrations of glucose can induce increases in c-fos and c-jun nuclear protein translocation.

In the condition of diabetes mellitus, hyperglycemia results in a series of metabolic disorders and plays a key role in the degeneration of nephrosis. There are many mechanisms by which high glucose concentrations exert pathological and physiological effects, one of which is the PKC signaling pathway. PKC normally exists in an inactive form in cytosol, and in an active form in the cell membrane and nucleus. An increase in PKC activity therefore suggests that PKC is translocated and activated. Various middle products, not involved in the progression of high blood glucose metabolism, can synthesize diacylglycerol (DAG), the main activator of PKC. Through a series of intracellular signaling pathways, such PKC activation can upregulate gene expression of ECM components, and further promote its protein expression ${ }^{[3,9,10]}$. When signals are translocated to the nucleolus, the transcription of certain genes is upregulated immediately. Most of these genes are protooncogenes whose expression products exert effects within the nucleolus. They can also encode certain key regulatory proteins and be distributed in various tissues and cells. The most important protooncogenes are the c-fos and c-jun gene expression products, all of which are phosphorylated proteins of middle molecular weight ${ }^{[4,11]}$. In cellular signaling pathways, $\mathrm{PKC}$ is an important molecule located upstream of c-fos and c-jun, both of which can participate in regulating gene expression of ECM components, such as CoIV, Fibronectin and laminin. In the promoter regions of the CoIV, FN and LN genes there are similar sites that can combine with c-fos and c-jun heterodimers. We chose GMC to investigate the effect of high glucose on c-fos and c-jun protein expression, and examine PKC activity in the membrane and cytosol of GMC under high glucose concentrations. The results indicate that at the early stage of high glucose treatment, protein expression products of c-fos and c-jun increase at the same time. However the duration of increased c-jun protein expression was longer than that of c-fos, as shown in the study of Shankland and Scholey ${ }^{[8]}$. At $24 \mathrm{~h}$ and 48 $\mathrm{h}$ of investigation, protein expression of c-fos and c-jun in GMC in the high concentration glucose+puerarin group was less than that of the high concentration glucose group, indicating that puerarin may inhibit the increase in c-fos and cjun protein expression in GMC under the influence of high glucose concentrations. At $48 \mathrm{~h}, \mathrm{PKC}$ activity in the cytosol of the high concentration glucose group was lower than that of the low concentration glucose group, but in the membrane fraction of the high concentration glucose group, PKC 
activity was higher than that of the low concentration glucose group. As PKC activation involves translocation from the cytosol to the membrane, the total PKC activity increase indicated that high glucose concentrations could not only promote PKC activation, but also up-regulate $\mathrm{PKC}$ protein expression. Our results demonstrate that after the addition of high concentration glucose+puerarin into GMC culture, puerarin inhibits PKC activity increases in GMC membranes at high glucose concentrations, consistent with diabetic nephropathy rats PKC membrane translocation in animal experiments ${ }^{[7]}$. All of these results further suggest that protein expression of c-fos and c-jun is up-regulated in GMC at high glucose concentrations, and CoIV synthesis is increased, both of which could be induced by PKC activation. Puerarin effectively inhibits this upregulation.

In summary, high glucose concentrations could induce PKC membrane translocation in GMC leading to the up-regulation of c-fos and c-jun gene products, an increase in CoIV synthesis and aggravating the occurrence and development of diabetic nephropathy, all of which could be inhibited by puerarin. Undoubtedly, these results will provide a molecular and pharmacological basis for puerarin's development as a new drug against diabetic nephropathy.

\section{References}

1 Gao YJ, Yue ZJ, Yan LJ, Nan CH, Li DM. Effects of high glucose condition on expression of extracellular matrix of glomerular mesangial cells in rats. Sect Clin Biochem \& Lab Med Foreign Med Sci 2004; 25: 99-101.

2 Kikkawa R, Koya D, Haneda M. Progression of diabetic nephropathy. Am J Kidney Dis 2003; 41: S19-21.

3 Haneda M, Koya D, Kikkawa R. Cellular mechanisms in the development and progression of diabetic nephropathy: activation of the DAG-PKC-ERK pathway. Am J Kidney Dis 2001; 38: $178-81$.

4 Zhang L, Zhang L, Zhao GS. The regulation of AP-1 on mitosin activating protein kinase signaling pathway. Pathophysiol Clin Med 2002; 20: 32-5.

5 Mao CP, Gu ZL. Researches of puerarin on pharmacological effect and clinical application. Chin J Hemorh 2004; 14: 13842.

6 Mei CL, Zhang LM, Chen L. Establish and identify rat mesangial cells. J Nephro Dial Transplant 1996; 5: 90-2.

7 Mao CP, Gu ZL, Cao L. Experimental studies on the effects and mechanisms of puerarin in diabetic uninephrectomized rats. Jiangsu Med J 2005; 31: 223-5.

8 Shankland SJ, Scholey JW. Expression of growth-related protooncogenes during diabetic renal hypertrophy. Kidney Int 1995; 47: 782-8.

9 Murphy M, McGinty A, Godson C. Protein kinase C: potential targets for intervention in diabetic nephropathy. Curr Opin Nephrol Hypertens 1998; 7: 563-70.

10 Koya D, King GL. Protein kinase C activation and the development of diabetic complications. Diabetes 1998; 47: 859-66.

11 Pariat M, Salvat C, Bebien M, Brockly F, Altieri E, Carillo S, et al. The sensitivity of c-Jun and c-Fos proteins to calpains depends on conformational determinants of the monomers and not on formation of dimers. Biochem J 2000; 345: 129-38. 